\title{
Feed additives can differentially modulate NF-kB (ReIA/p65), IGF-1, GLUT2, and SGLT1 gene expression in porcine jejunal explants
}

\author{
Hebert Silveira ${ }^{1}$, Antonio Diego Brandão Melo $^{2}$ (iD), Cristiano Bortoluzzi ${ }^{3}$ (iD, \\ Leandro Batista Costa ${ }^{2}$ (D), Marcos Horácio Rostagno ${ }^{4}$, Allan Paul Schinckel ${ }^{4}$ (iD, \\ Cesar Augusto Pospissil Garbossa ${ }^{5}$ (iD, Vinícius de Souza Cantarelli $6^{*}$
}

\author{
${ }^{1}$ Agroceres Multimix, Rio Claro, SP, Brasil. \\ ${ }^{2}$ Pontífica Universidade Católica do Paraná, Curitiba, PR, Brasil. \\ ${ }^{3}$ University of Georgia, Department of Poultry Science, Athens, USA. \\ ${ }^{4}$ Purdue University, Department of Animal Science, West Lafayette, USA. \\ ${ }^{5}$ Universidade de São Paulo, Departamento de Nutrição e Produção Animal, Pirassununga, SP, Brasil. \\ ${ }^{6}$ Universidade Federal de Lavras, Departamento de Zootecnia, Lavras, MG, Brasil.
}

\begin{abstract}
The intestinal gene expression of RelA/p65 (NF- $\kappa \mathrm{B})$, insulin growth factor 1 (IGF-1), glucose transporter 2 (GLUT2), and $\mathrm{Na}+$ /dependent glucose transporter 1 (SGLT1) were evaluated in response to benzoic acid, yeast culture, L-glutamine, and oregano essential oil, using an ex vivo model. Six piglets weighing approximately $20 \mathrm{~kg}$ each were sacrificed, and their jejunum was collected and segmented into five 2-cm explants. Each explant was immersed in cell culture medium according to one of the following treatments: control (without additive), $0.5 \%$ benzoic acid, $1 \%$ yeast culture, $1 \% \mathrm{~L}$-glutamine, and $0.015 \%$ oregano oil. Gene expression was evaluated using RT-PCR. Yeast culture up-regulated the gene expression of RelA/p65, IGF-1, GLUT2, and SGLT1 in comparison with control. In addition, jejunal exposure to L-glutamine and oregano oil increased mRNA levels of GLUT2 compared with the control treatment. Exposure to oregano oil increased intestinal SGLT1 gene expression, while benzoic acid reduced SGLT1 expression compared with the control. Feed additives can differently modulate the gene expression of immune response, gut development, and glucose absorption in jejunal explants. These findings can contribute for a better understanding of the trophic action of these feed additives into the diets to optimize animal performance.
\end{abstract}

Key Words: chemosensors, glucose, piglet, RT-PCR, swine, trophic effects

\section{Introduction}

The early weaning of piglets is a common practice to increase sow productivity and reduce costs. However, early weaning can lead to intestinal inflammation and decreased intestinal integrity, which compromises nutrient digestion and absorption until the adaptation to a solid diet (Lackeyram et al., 2010). Avoiding impaired intestinal integrity is crucial to prevent perturbation of brush-border enzyme activity, loss of protein synthesis, and reduced gene expression of mucosal DNA and RNA, which cause lower gene expression resulting in reduced nutrient absorption due to decreased villus height and increased crypt depth (Khan and Islam, 2012) caused by the lower production of digestive enzymes and lower contact area with the feed.

Received: May 15, 2018

Accepted: July 26, 2018

*Corresponding author: vinicius@dzo.ufla.br

Copyright (c) 2018 Sociedade Brasileira de Zootecnia. This is an Open Access article distributed under the terms of the Creative Commons Attribution License (http://creativecommons.org/licenses/by/4.0/), which permits unrestricted use, distribution, and reproduction in any medium, provided the original work is properly cited.
The ingestion of feed additives that efficiently re-establish intestinal health, especially during early weaning period, has been target of some investigations (Bahar et al., 2012; Tucci et al., 2014; Boroojeni et al., 2018), especially after the ban of antibiotics use as growth promoters in the Europe Union in 2006.

The focus on past feed additive research was to identify products with antimicrobial effects to replace antibiotics used as growth promoters (Kommera et al., 2006; Michiels et al., 2009). The emphasis of recent research has been to understand the other effects of feed additives, including the functional balance of immune response, development of gut, and glucose absorption into intestinal tract (Shen et al., 2009; Song et al., 2010; Wu et al., 2011; Gao et al., 2012; Melo et al., 2016; Waititu et al., 2016).

Glutamine is an amino acid that plays important roles in regulating gene expression, cell signalling, antioxidative responses, neurotransmission, and immunity; additionally, it is a major metabolic fuel for the small intestine to maintain its digestive function and to protect the integrity of the intestinal mucosa (Wu et al., 2011). 
Dietary supplementation with yeast culture has a positive effect on performance and health in weaned piglets through stimulating the immune system and maintaining a favourable intestinal environment (Heugten et al., 2003). According to Tan et al. (2015) the use of oregano essential oil improved performance of their piglets through reducing oxidative stress. Benzoic acid has the capacity to increase the digestibility of the diet and, consequently, improve the performance of weaned piglets (Zhang et al., 2016). In this way, all these additives have beneficial effects over the performance of piglets; however, the mode of action should be better understood.

Ex vivo techniques have been recently used to evaluate the effect of feed additives on immune response in swine tissues challenged by lipopolysaccharides (Smith et al., 2011; Bahar et al., 2012; Leonard et al., 2012). These techniques, in which intestine explants are exposed to different treatments, are a rapid, less expensive, specific, and reliable experimental model to determine the trophic effects of feed additives on intestinal mucosa (Basso et al., 2013; Bortoluzzi et al., 2016; Melo et al., 2016).

$\mathrm{NF}-\mathrm{kB}$ is of major importance for the activation of the transcription of a variety of genes related to cytokine production (May and Ghosh, 1998); IGF-1 plays a vital role in the modulation of piglet intestinal post-natal growth (Burrin et al., 1996); the glucose transporters GLUT2 and SGLT1 are crucial for adequate absorption of glucose in the small intestine (Rodriguez et al., 2004). The evaluation of these genes can contribute to understand how the additives improve the performance of piglets.

Due to the similarities in intestinal physiology between pigs and humans, studies that examine the nutritional influences on intestinal health are preferably carried out in pig models (Roura et al., 2016). The objective of this study was to evaluate jejunal gene expression of NF- $\mathrm{kB}$, IGF-1, GLUT2, and SGLT1 in response to yeast culture, benzoic acid, L-glutamine, and oregano essential oil exposure using an ex vivo model.

\section{Material and Methods}

All experimental procedures were approved by the local Animal Care and Use Committee (case no. 1111000138). The experiment was performed in West Lafayette, Indiana, USA ( $40^{\circ} 27^{\prime} 19^{\prime \prime} \mathrm{N}$ and $\left.86^{\circ} 54^{\prime} 42^{\prime \prime} \mathrm{W}\right)$.

Jejunal tissues from six piglets $(20 \mathrm{~kg})$ were collected $30 \mathrm{~cm}$ from the stomach. Five intestinal samples were collected from each pig for assignment to the treatments. The samples were immediately washed post-harvest with phosphate buffer solution (PBS) using pisset until there were no more contents. Then, the samples were immersed individually in $50 \mathrm{~mL}$ polypropylene tubes containing a buffer solution $(50 \mathrm{mM} / \mathrm{L}$ mannitol, $2 \mathrm{mM} / \mathrm{L}$ tris-HCL, $\mathrm{pH}$ 7.4) with antibiotics for $15 \mathrm{~min}$, kept in an insulated box with ice, and transported to laboratory. The buffer solution was made using an ultra-pure water containing an antibiotic mixture of penicillin, neomycin, and streptomycin, $1 \%$ $(0.1 \mathrm{~mL} / \mathrm{mL}$ of solution, Sigma Aldrich, St. Louis, MO, EUA) to reduce microbial presence in the samples.

Then the tissues were rinsed with PBS and immersed for 60 min in cell culture media (Dulbecco's Modified Eagle Medium (DMEM) - high glucose HEPES modification, with $4500 \mathrm{mg} / \mathrm{L}$ glucose, $25 \mathrm{mM}$ HEPES, and sodium bicarbonate, without L-glutamine and sodium pyruvate, sterile-filtered liquid, suitable for cell culture - DMEM). The treatments evaluated were: control (without additives), $1 \%$ L-glutamine ( $\geq 99 \%$; Sigma Aldrich, St. Louis, MO, EUA), $1 \%$ yeast culture (Varied Industries Corporation, Mason, IO, EUA), $0.5 \%$ benzoic acid ( $\geq 99.5 \%$; Sigma Aldrich, St. Louis, MO, EUA), and $0.015 \%$ oregano essential oil (100\%; NOW Foods, Bloomingdale, IL, EUA). The tissues were incubated at $37^{\circ} \mathrm{C}$ in a closed Falcon tube. Some additives were not soluble in the medium; thus, the plates were placed on a rocking platform to keep the tissue in contact with the additive.

After the incubation, the tissues were rinsed with PBS and stored at $-80{ }^{\circ} \mathrm{C}$ in a cryovial tube with $0.5 \mathrm{~mL}$ of TRIzol $^{\circledR}$ reagent (Invitrogen, China) for subsequent RNA extraction, cDNA synthesis, and gene expression analyses. All experimental procedures were performed in accordance to the protocol outlined by Bortoluzzi et al. (2016).

Total RNA was isolated from approximately $50 \mathrm{mg}$ jejunum tissue samples using TRIzol ${ }^{\circledR}$ reagent (Invitrogen, China), following the manufacturer's instructions. Precipitated RNA was suspended in $20 \mu \mathrm{L}$ of RNAse free water and treated with DNAse (Invitrogen, China), then stored at $-80{ }^{\circ} \mathrm{C}$. RNA quantity was assessed by UV spectrophotometer. To synthesize the cDNA, the same RNA quantity per sample was used, which was produced by diluting the higher RNA concentration with RNAse free water. First-strand cDNA was synthesized from $5 \mu \mathrm{L}$ of total RNA using oligodT primers and Superscript II reverse transcriptase, in accordance with the manufacturer's instructions (Invitrogen, China). Synthesized cDNA was diluted five times with sterile water and stored at $-20{ }^{\circ} \mathrm{C}$ before use.

The gene expression analyses were performed to the following gut genes: RelA/p65 (Santos et al., 2007), IGF-1 (Yin et al., 2009), GLUT2, and SGLT1 (Song et al., 2010) with GAPDH (Smith et al., 2011) as endogenous control; 
primers are shown in Table 1. Amplification of RT-PCR was performed in $25 \mu \mathrm{L}$ of reaction mixture containing $5 \mu \mathrm{L}$ of diluted cDNA, $12.5 \mu \mathrm{L}$ of SYBR Green PCR Master Mix (Roche, Switzerland), $2.5 \mu \mathrm{L}$ of each primer, and $3 \mu \mathrm{L}$ of PCR-grade water. The PCR procedure for RelA/p65 consisted of heating the reaction mixture to $95^{\circ} \mathrm{C}$ for $5 \mathrm{~min}$, followed by 40 cycles of $94{ }^{\circ} \mathrm{C}$ for $30 \mathrm{~s}, 54^{\circ} \mathrm{C}$ for $30 \mathrm{~s}$, and $72{ }^{\circ} \mathrm{C}$ for $40 \mathrm{~s}$. IGF-1 had a heating reaction of $95^{\circ} \mathrm{C}$ for 5 min followed by 40 cycles of $94{ }^{\circ} \mathrm{C}$ for $30 \mathrm{~s}, 56{ }^{\circ} \mathrm{C}$ for $30 \mathrm{~s}$, and $72{ }^{\circ} \mathrm{C}$ for $40 \mathrm{~s}$. The GLUT2 heating reaction was $94{ }^{\circ} \mathrm{C}$ for $5 \mathrm{~min}$ followed by 40 cycles of $94{ }^{\circ} \mathrm{C}$ for $30 \mathrm{~s}$, $51^{\circ} \mathrm{C}$ for $30 \mathrm{~s}$, and $72{ }^{\circ} \mathrm{C}$ for $40 \mathrm{~s}$. The heating reaction for SGLT1 was $94^{\circ} \mathrm{C}$ for $5 \mathrm{~min}$ followed by 40 cycles of $94^{\circ} \mathrm{C}$ for $30 \mathrm{~s}, 53{ }^{\circ} \mathrm{C}$ for $30 \mathrm{~s}$, and $72{ }^{\circ} \mathrm{C}$ for $40 \mathrm{~s}$.

A dissociation curve was run for each plate to confirm the production of a single product. Data of PCR obtained from the ABI 7500 Real-time PCR System were automatically analysed by Applied Bio systems Software. The relative standard-curve method was used to quantify the mRNA concentrations of each gene in relation to the reference gene (GAPDH). The mRNA relative abundance was calculated as described by Pfaffl (2001). Relative mRNA expression was calculated according to the methods proposed by Livak and Schmittgen (2001). All samples were analysed in quadruplicate.

The analysis of variance was performed according to the statistical model below:

$$
Y i j=\mu+G i+\varepsilon i j,
$$

in which $Y i j=$ observation of the effect of the treatment $i$ and at replication $j, \mu=$ overall mean, $G i=$ effect of treatment, and $\varepsilon i j=$ random error associated with each observation.

For statistical analysis, each jejunal explant collected from the piglets (five explants/piglet) was considered as one experimental unit ( $\mathrm{n}=$ six replicates/treatment). Cochran's test was carried out to verify data homogeneity. The effect of treatments on gene expression levels was assessed using the General Linear Model (GLM), following Dunnett's test. Significance was determined to be $\mathrm{P} \leq 0.05$.

\section{Results}

The addition of $1 \%$ yeast culture increased $(\mathrm{P}<0.05)$ the mRNA levels of RelA/p65 6.36 \pm 2.05 -fold compared with control treatment (Figure 1). The mRNA levels of RelA/p65 after Benzoic acid, L-glutamine, and oregano essential oil exposure were not different from the control treatment. Only the porcine jejunum explants exposed to $1 \%$ of yeast culture had increased levels of mRNA level for IGF-1, 4.58 \pm 1.14 -fold greater than control (Figure 2).

Intestinal GLUT2 gene expression was up-regulated by $1 \%$ of yeast culture (3.47 \pm 0.56 -fold greater than control), $1 \%$ L-glutamine $(2.82 \pm 0.68$-fold greater than control), and $0.015 \%$ oregano essential oil $(5.62 \pm 0.89$-fold greater than control) (Figure 3). Furthermore, the addition of $1 \%$ of yeast culture and $0.015 \%$ oregano oil also increased intestinal SGLT1 gene expression compared with the control (3.58 $\pm 0.42-$ and 3.16 \pm 0.44 -fold, respectively)

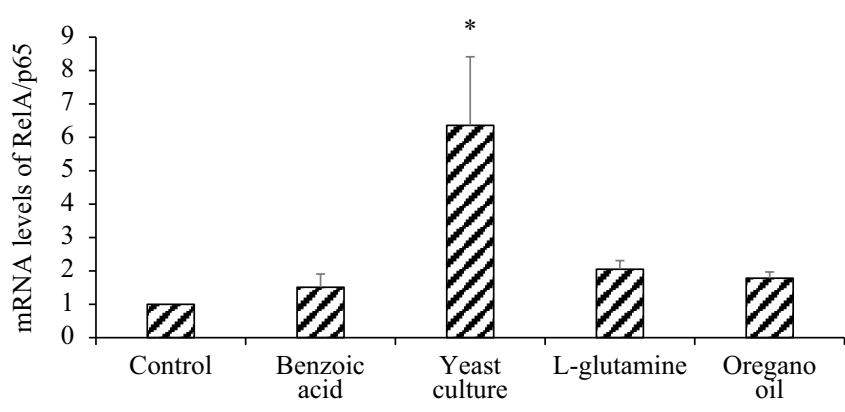

SEM - standard error of the mean

${ }^{*} \mathrm{P}<0.05$ control vs treatment.

There were six replicates per treatment.

Figure 1 - Gene expression of RelA/p65 in porcine jejunal explants induced by different feed additives determined by qRT-PCR (expressed as fold greater than control based on $2-\Delta \Delta \mathrm{Ct}$, using GAPDH as reference gene) means with \pm SEM.

Table 1 - Gut markers and sequence of primers to real time PCR

\begin{tabular}{llcc}
\hline Gut marker & Primer & Sequence (5'-3') & Reference \\
\hline \multirow{2}{*}{ GAPDH } & Forward & CAGCAATGCCTCCTGTACCA & Smith et al. (2011) \\
& Reverse & ACGATGCCGAAGTTGTCATG & Song et al. (2010) \\
GLUT2 & Forward & CAGGGGTGCTATTGGTGC & Song et al. (2010) \\
& Reverse & TTCCTTGCTTTGGCTTCC & Santos et al. (2007) \\
p65/RelA & Forward & CATCATCGTCCTGGTCGTC & Yin et al. (2009) \\
\multirow{2}{*}{ IGF-1 } & Feverse & TGCCTCCTCTTCCTTGGT & GGAACACGATGGCCACTTG \\
& Forward & AAGAGGACATCGAGGTGTATTTCAC & CTGTAACCATGAGGCTGAGA \\
\hline
\end{tabular}

PCR - polymerase chain reaction. 
(Figure 4). Benzoic acid was a suppressor of SGLT1 mRNA levels (66\% lesser than control), while L-glutamine did not alter the expression of this marker of glucose transport.

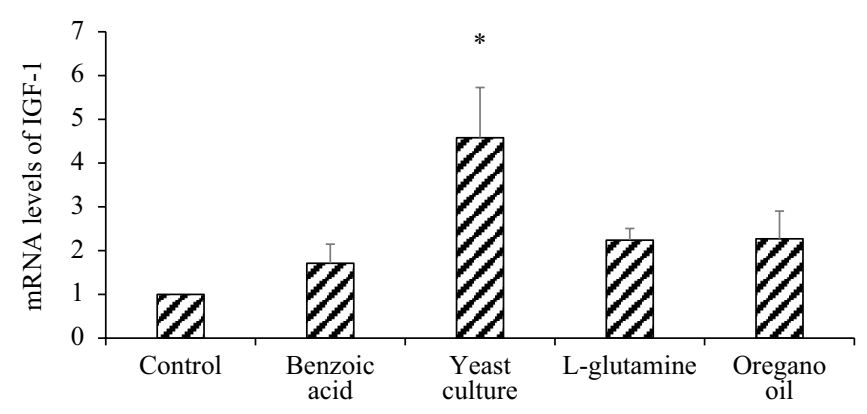

SEM - standard error of the mean.

${ }^{*} \mathrm{P}<0.05$ control vs treatment.

There were six replicates per treatment.

Figure 2 - Gene expression of IGF-1 in porcine jejunal explants induced by different feed additives determined by qRT-PCR (expressed as fold greater than control based on $2-\Delta \Delta \mathrm{Ct}$, using GAPDH as reference gene) means with \pm SEM.

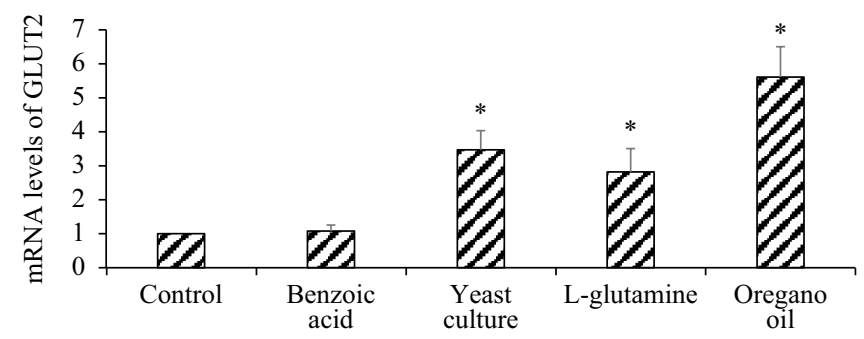

SEM - standard error of the mean.

${ }^{*} \mathrm{P}<0.05$ control vs treatment.

There were six replicates per treatment.

Figure 3 - Gene expression of GLUT2 in porcine jejunal explants induced by different feed additives determined by qRT-PCR (expressed as fold greater than control based on 2- $\Delta \Delta \mathrm{Ct}$, using GAPDH as reference gene) means with \pm SEM.

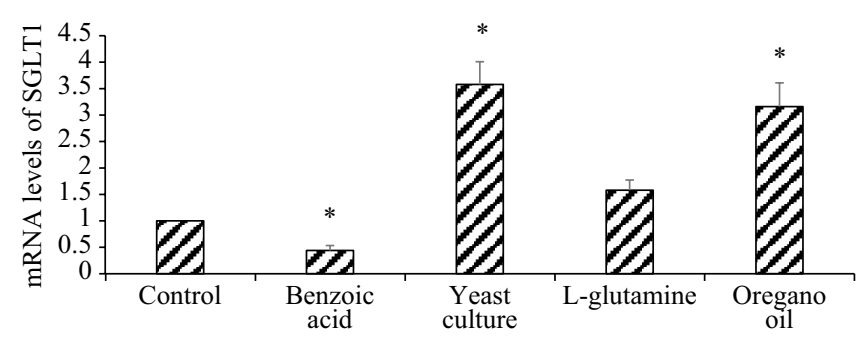

SEM - standard error of the mean.

${ }^{*} \mathrm{P}<0.05$ control vs treatment.

There were six replicates per treatment.

Figure 4 - Gene expression of SGLT1 in porcine jejunal explants induced by different feed additives determined by qRT-PCR (expressed as fold greater than control based on 2- $\Delta \Delta \mathrm{Ct}$, using GAPDH as reference gene) means with \pm SEM.

\section{Discussion}

$\mathrm{NF}-\kappa \mathrm{B}$ is a transcription activator of genes involved in immune response, including the stimulation of $\mathrm{T}$ cell activity. An abnormal overstimulation of NF- $\mathrm{kB}$ is dangerous to the health of the host, due the potent pro-inflammatory effects of T cells (Baeuerle and Henkel, 1994). The modulation of pro- and anti-inflammatory cytokines must be considered as an important property of feed additives to control immune response (Shen et al., 2009; Gao et al., 2012).

In this study, up-regulation of RelA/p65 (NF- $\mathrm{kB})$ gene expression was produced by yeast culture; similar results were found by Wang et al. (2016), evaluating live yeast over the expression of this gene on the gut of broilers. In the same way, our results agree with Shen et al. (2009), who reported that yeast culture increased IFN- $\gamma$, a T helper-1 cytokine of the intestinal mucosa of piglets, probably induced by the NF- $\mathrm{KB}$ molecule, as this molecule.

An alternative hypothesis is that, in animal production, this up-regulation could deviate the energy destined for muscular growth to immune response and reduce body weight gain. Positive effects of yeast culture intake have been reported, including improvement of intestinal integrity, feed digestibility, and growth performance (Shen et al., 2009). Wang et al. (2016) evaluating broilers challenged and unchallenged with $E$. coli and receiving supplementation of live yeast, observed a lower expression of NF- $\mathrm{kB}$ for animals challenged and an increase in animals unchallenged. It demonstrates that live yeast can affect the expression, modulating the immune response according to the environment, thus causing beneficial effects to the host.

IGF-1 has a wide range of biological actions, including the stimuli to cell proliferation and differentiation in many tissues (Jones and Clemmons, 1995), and plays a vital role in the modulation of piglet intestinal postnatal growth (Burrin et al., 1996). Besides the effects of the intestinal growth, this molecule has a great effect over the growth of the animal during its life (Hellström et al., 2016). Therefore, the absence of IGF-1 could negatively affect animal growth and productivity.

Jiang et al. (2015) also found that supplementation of piglet feed with yeast improve the serum IGF-1 concentration as well as improves animal performance. The beneficial effects could be associated with the composition of cell wall components of yeast, which is a complex polymer and composed of $\beta$-glucans, $\alpha$-mannans, mannoproteins, and a minor component of chitin.

The literature reports that pro-inflammatory cytokines released by NF- $\kappa \mathrm{B}$ activation can increase the resistance of hepatic growth hormone receptor and, consequently, 
reduce synthesis of IGF-1 in target tissues (Broussard et al., 2001). However, it has also been reported that IGF-1 is an up-regulator of RelA/p65 (Zhao et al., 2011). Probably, a negative feedback system may control the gene expression of IGF-1 and pro-inflammatory cytokines released by $\mathrm{NF}-\mathrm{\kappa B}$ activation. In our findings, without the induction of inflammatory downstream, the effect of yeast culture increased the expression of RelA/p65 (NF-kB) and IGF-1.

The expression of glucose transporter genes such as GLUT2 and SGLT1 are crucial for adequate absorption of glucose in the small intestine (Rodriguez et al., 2004). Low expression of GLUT2 and SGLT1 are associated to a minor capitation of intestinal glucose in piglets (Song et al., 2010).

GLUT2 acts as a facilitator of glucose diffusion through lipid bilayers in the basolateral membrane, transporting glucose and fructose, providing a common exit pathway to the blood (Breves et al., 2007). The second glucose transporter, SGLT1, mediates $\mathrm{Na}^{+}$/glucose co-transport function both in kidney and intestine as a secondary active transporter (Breves et al., 2007).

Some glucose molecules can be rapidly captured by SGLT1 and GLUT2, which are the only co-transporters able to actively transport glucose against the concentration gradient (Kellett and Brot-Laroche, 2005). Therefore, apical GLUT2 can provide a major route of monosaccharide absorption by which absorptive capacity is rapidly and precisely up-regulated to match the dietary intake of carbohydrates. Apical GLUT2 is not only regulated by long and short-term supply of dietary carbohydrates, but also by local and endocrine hormones, cellular energy status, stress, and diabetes. Regulation occurs through a network of intracellular signalling pathways (Kellett and Brot-Laroche, 2005). In vitro IGF-I can stimulate cellular transport processes, including facilitated glucose uptake (Prosser et al., 1987). Alexander and Carey (1999) verified an increase in SGLT1 gene expression and increase in proliferation of enterocytes in IGF-I-treated piglets.

In this study, IGF-1, SGLT1, and GLUT2 gene expression increased in response to the yeast culture, and there may be a relationship between these variables, as a greater IGF-1 gene expression could result in increased gene expression of SGLT1 and GLUT2, as suggested by Prosser et al. (1987) and observed in the present trial for the explants exposed to yeast culture.

Glutamine is an amino acid required for the synthesis of purine and pyrimidine, essential for gene expression, and proliferation of cells, including cells of intestinal mucosa and intraepithelial lymphocytes (Wu et al., 2011; Tucci et al., 2014). Consequently, the use of $1 \%$ glutamine to weanling piglets enhances intestinal oxidative-defence capacity, prevents jejunal atrophy, promotes small intestine growth, and body weight gain in weaned piglets (Wu et al., 2011). He et al. (2016) also found that $1 \%$ glutamine improves the performance of weaned piglets and disaccharide enzyme activity, which could provide more substrate for the glucose transports; thus, the up-regulation of GLUT2 by glutamine is interesting, which can contribute with intestinal health, increasing the absorption of cell energy substrates.

GLUT2 and SGLT1 gene expressions were upregulated by the herb mixture of Cortex Phellodendron, Rhizome Atractylodes, Agastache rugosa, and Gypsum Fibrosum in the small intestine of pigs subjected to heat stress (Song et al., 2010). In this trial, oregano essential oil was also an up-regulator of GLUT2 and SGLT1 mRNA. The correct use of herb compounds can optimize glucose absorption, in absence of a challenge, as showed in the present study.

Among the feed additives tested, only benzoic acid acted as a down-regulator of glucose co-transporters. The absence of GLUT2 regulation and the down-regulation of SGLT1 gene expression after benzoic acid exposure could be associated to its acidifying effect into the medium and its mucosal stimulus to mucin production. The reduction in $\mathrm{pH}$ was observed by changes in the colour of the medium after the addition of benzoic acid. However, additional studies are necessary to understand these results.

The knowledge about mucosal response to feed additives included into the diet has a great importance for piglet production, especially due to the high stress promoted by weaning process associated to glucocorticoid release and reduction of feed intake, which contributes to a reduction in glucose co-transporter gene expression, reduction in the intestinal villus height and crypt depth, and increase in the intestinal inflammatory response.

The gene expression of beneficial intestinal health genes in the mucosa is a complex point of investigation. Several in vivo conditions impact gene expression, including the food consumed, established microbiota, intestinal and immune maturity, and environmental conditions. Thus, the modulation of gene expression in response to a feed additive should be investigated without these confounding conditions, to certify if its use can induce gene expression (Melo et al., 2016).

\section{Conclusions}

Feed additives differently modulate the gene expression of immune response, gut development, and glucose absorption in jejunal explants. These findings can contribute 
for a better understanding of the trophic action of these feed additives into the diets to optimize the animal performance.

\section{Acknowledgments}

The authors want to acknowledge the Conselho Nacional de Desenvolvimento Científico e Tecnológico (CNPq), Coordenação de Aperfeiçoamento de Pessoal de Nível Superior (CAPES) - Finance Code 001, Fundação de Amparo à Pesquisa do Estado de Minas Gerais (FAPEMIG), Fundação de Amparo à Pesquisa do Estado de São Paulo (FAPESP), Instituto Nacional de Ciência e Tecnologia de Ciência Animal (INCT-CA), and Purdue University - USA, for the financial support of this research. The first author thanks CAPES for the scholarship granted for a sandwich exchange program in Purdue University.

\section{References}

Alexander, A. N. and Carey, H. V. 1999. Oral IGF-I enhances nutrient and electrolyte absorption in neonatal piglet intestine. American Journal of Physiology 277:619-625.

Baeuerle, P. A. and Henkel, T. 1994. Function and activation of $\mathrm{NF}-\kappa \mathrm{B}$ in the immune system. Annual Review of Immunology 12:141-179. https://doi.org/10.1146/annurev.iy.12.040194.001041

Bahar, B.; O’Doherty, J. V.; Hayes, M. and Sweeney, T. 2012. Extracts of brown seaweeds can attenuate the bacterial lipopolysaccharideinduced pro-inflammatory response in the porcine colon ex vivo. Journal of Animal Science 90:46-48. https://doi.org/ $10.2527 /$ jas. 53944

Basso, K.; Gomes, F. and Bracarense, A. P. 2013. Deoxynivalenol and fumonisin, alone or in combination, induce changes on intestinal junction complexes and in E-cadherin expression. Toxins 5:23412352. https://doi.org/10.3390/toxins5122341

Boroojeni, F. G.; Männer, K. and Zentek, J. 2018. The impacts of Macleaya cordata extract and naringin inclusion in post-weaning piglet diets on performance, nutrient digestibility and intestinal histomorphology. Archives of Animal Nutrition 72:178-189. https://doi.org/10.1080/1745039X.2018.1459342

Bortoluzzi, C.; Menten, J. F. M.; Silveira, H.; Melo, A. D. B. and Rostagno, M. H. 2016. Hops $\beta$-acids (Humulus lupulus) decrease intestinal gene expression of proinflammatory cytokines in an exvivo model. The Journal of Applied Poultry Research 25:191-196. https://doi.org/10.3382/japr/pfw001

Breves, G.; Kock, J. and Schröder, B. 2007. Transport of nutrients and electrolytes across the intestinal wall in pigs. Livestock Science 109:4-13. https://doi.org/10.1016/j.livsci.2007.01.021

Broussard, S. R.; Zhou, J. H.; Venters, H. D.; Bluthé, R. M.; Freund, G. G.; Johnson, R. W.; Dantzer, R. and Kelley, K. W. 2001. At the interface of environment-immune interactions: Cytokine and growth-factor receptors. Journal of Animal Science 79:268-284. https://doi.org/10.2527/jas2001.79E-SupplE268x

Burrin, D. G.; Wester, T. J.; Davis, T. A.; Amick, S. and Heath, J. P. 1996. Orally administered IGF-I increases intestinal mucosal growth in formula-fed neonatal pigs. American Journal of Physiology 270:1085-1091.

Gao, Y. Y.; Xie, Q. M.; Jin, L.; Sun, B. L.; Ji, J.; Chen, F.; Ma, J. Y. and Bi, Y. Z. 2012. Supplementation of xanthophylls decreased proinflammatory and increased anti-inflammatory cytokines in hens and chicks. British Journal of Nutrition 108:1746-1755. https://doi.org/10.1017/S0007114512000025

He, J.; Feng, G. D.; Ao, X.; Li, Y. F.; Qian, H. X.; Liu, J. B.; Bai, G. Y. and He, Z. Z. 2016. Effects of L-glutamine on growth performance, antioxidant ability, immunity and expression of genes related to intestinal health in weanling pigs. Livestock Science 189:102-109. https://doi.org/10.1016/j.livsci.2016.05.009

Hellström, A.; Ley, D.; Hansen-Pupp, I.; Hallberg, B.; Ramenghi, L.; Löfqvist, C.; Smith, L. E. and Hård, A. 2016. Role of insulinlike growth factor 1 in fetal development and in the early postnatal life of premature infants. American Journal of Perinatology 33:1067-1071. https://doi.org/10.1055/s-0036-1586109

Heugten, E.; Funderburke, D. and Dorton, K. 2003. Growth performance, nutrient digestibility, and fecal microflora in weanling pigs fed live yeast. Journal of Animal Science 81:1004-1012. https://doi.org/10.2527/2003.8141004x

Jiang, Z.; Wei, S.; Wang, Z.; Zhu, C.; Hu, S.; Zheng, C.; Chen, Z.; $\mathrm{Hu}$, Y.; Wang, L.; Ma, X. and Yang, X. 2015. Effects of different forms of yeast Saccharomyces cerevisiae on growth performance, intestinal development, and systemic immunity in early-weaned piglets. Journal of Animal Science and Biotechnology 6:47. https://doi.org/10.1186/s40104-015-0046-8

Jones, J. I. and Clemmons, D. R. 1995. Insulin-like growth factors and their binding proteins: biological actions. Endocrine Reviews 16:3-34.

Kellett, G. L. and Brot-Laroche, E. 2005. Apical GLUT2: a major pathway of intestinal sugar absorption. Diabetes 54:3056-3062. https://doi.org/10.2337/diabetes.54.10.3056

Khan, J. and Islam, M. N. 2012. Morphology of the intestinal barrier in different physiological and pathological conditions. p.134-152. In: Histopathology - Reviews and recent advances; Poblet, E. Rijeka, Croatia, InTech. https://doi.org/10.5772/50659

Kommera, S. K.; Mateo, R. D.; Neher, F. J. and Kim, S. W. 2006. Phytobiotics and organic acids as potential alternatives to the use of antibiotics in nursery pig diets. Asian-Australasian Journal of Animal Sciences 19:1784-1789. https://doi.org/10.5713/ajas.2006.1784

Lackeyram, D.; Yang, C.; Archbold, T.; Swanson, K. C. and Fan, M. Z. 2010. Early weaning reduces small intestinal alkaline phosphatase expression in pigs. The Journal of Nutrition 140:461-468. https:// doi.org/10.3945/jn.109.117267

Leonard, S. S.; Sweeney, T.; Bahar, B. and O’Doherty, J. V. 2012. Effect of maternal seaweed extract supplementation on suckling piglet growth, humoral immunity, selected microflora, and immune response after an ex vivo lipopolysaccharide challenge. Journal of Animal Science 90:505-514. https://doi.org/10.2527/jas.2010-3243

Livak, K. J. and Schmittgen, T. D. 2001. Analysis of relative gene expression data using real-time quantitative $\mathrm{PCR}$ and the 2- $\Delta \Delta \mathrm{Ct}$ method. Methods 25:402-408. https://doi.org/10.1006/ meth.2001.1262

May, M. J. and Ghosh, S. 1998. Signal transduction through NF-кB Immunology Today 19:80-88. https://doi.org/10.1016/S01675699(97)01197-3

Melo, A. D. B.; Silveira, H.; Bortoluzzi, C.; Lara, L. J.; Garbossa, C. A. P.; Preis, G.; Costa, L. B. and Rostagno, M. H. 2016. Intestinal alkaline phosphatase and sodium butyrate may be beneficial in attenuating LPS-induced intestinal inflammation. Genetics and Molecular Research 15:1-9. https://doi.org/10.4238/gmr15048875

Michiels, J.; Missotten, J. A. M.; Fremaut, D.; De Smet, S. and Dierick, N. A. 2009. In vitro characterization of the antimicrobial activity of selected essential oil components and binary combinations against the pig gut flora. Animal Feed Science and Technology 151:111-127. https://doi.org/10.1016/j.anifeedsci.2009.01.004

Pfaffl, M. W. 2001. A new mathematical model for relative quantification in real-time RT-PCR. Nucleic Acids Research 29:e45. https://doi.org/10.1093/nar/29.9.e45 
Prosser, C. G.; Sankaran, L.; Henninghausen, L. and Topper, Y. J. 1987. Comparison of the roles of insulin and insulin-like growth factor-I in casein gene expression and in the development of alpha-lactalbumin and glucose transport in the mouse mammary epithelial cell. Endocrinology 120:1411-1416. https://doi. org/10.1210/endo-120-4-1411

Rodriguez, S. M.; Guimarães, K. C.; Matthews, J. C.; McLeod, K. R.; Baldwin, R. L. and Harmon, D. L. 2004. Influence of abomasal carbohydrates on small intestinal sodium-dependent glucose cotransporter activity and abundance in steers. Journal of Animal Science 82:3015-3023. https://doi.org/10.2527/2004.82103015x

Roura, E.; Koopmans, S. J.; Lallès, J. P.; Le Huerou-Luron, I.; de Jager, N.; Schuurman, T. and Val-Laillet, D. 2016. Critical review evaluating the pig as a model for human nutritional physiology. Nutrition Research Reviews 29:60-90. https://doi.org/10.1017/S0954422416000020

Santos, T.; Diaz-San Segundo, F. and Grubman, M. J. 2007. Degradation of nuclear factor kappa B during foot-and-mouth disease virus infection. Journal of Virology 81:12803-12815. https://doi.org/10.1128/JVI.01467-07

Shen, Y. B. X. S.; Piao, S. W.; Kim, L.; Wang, P.; Liu, I.; Yoon, Y. and Zhen, Y. G. 2009. Effects of yeast culture supplementation on growth performance, intestinal health, and immune response of nursery pigs. Journal of Animal Science 87:2614-2624. https://doi. org/10.2527/jas.2008-1512

Smith, A. G.; O’Doherty, J. V.; Reilly, P.; Ryan, M. T.; Bahar, B. and Sweeney, T. 2011. The effects of laminarin derived from Laminaria digitata on measurements of gut health: Selected bacterial populations, intestinal fermentation, mucin gene expression and cytokine gene expression in the pig. British Journal of Nutrition 105:669-677. https://doi.org/10.1017/S0007114510004277

Song, X.; Xu, J.; Wanga, T. and Liu, F. 2010. Traditional Chinese medicine decoction enhances growth performance and intestinal glucose absorption in heat stressed pigs by up-regulating the expressions of SGLT1 and GLUT2 mRNA. Livestock Science 128:75-81. https://doi.org/10.1016/j.livsci.2009.11.002

Tan, C.; Wei, H.; Sun, H.; Ao, J.; Long, G.; Jiang, S. and Peng, J. 2015. Effects of dietary supplementation of oregano essential oil to sows on oxidative stress status, lactation feed intake of sows, and piglet performance. Biomed Research International 2015:525218. https://doi.org/10.1155/2015/525218
Tucci, F. M.; Thomaz, M. C.; Hannas, M. I.; Scandolera, A. J. and Budiño, F. E. L. 2014. Efeitos da adição de agentes tróficos na dieta de leitões desmamados sobre a expressão da enzima ornitina descarboxilase, os conteúdos de proteína e DNA e o desempenho. Ciência Animal Brasileira 15:377-383. https://doi. org/10.1590/1089-6891v15i412587

Waititu, S. M.; Yin, F.; Patterson, R.; Rodriguez-Lecompte, J. C. and Nyachoti, C. M. 2016. Short-term effect of supplemental yeast extract without or with feed enzymes on growth performance, immune status and gut structure of weaned pigs challenged with Escherichia coli lipopolysaccharide. Journal of Animal Science and Biotechnology 7:64. https://doi.org/10.1186/ s40104-016-0125-5

Wang, W.; Li, Z.; Han, Q.; Guo, Y.; Zhang, B. and D'inca, D. 2016. Dietary live yeast and mannan-oligosaccharide supplementation attenuate intestinal inflammation and barrier dysfunction induced by Escherichia coli in broilers. British Journal of Nutrition 116:1878-1888. https://doi.org/10.1017/S0007114516004116

Wu, G.; Bazer, F. W.; Johnson, G. A.; Knabe, D. A.; Burghardt, R. C.; Spencer, T. E.; Li, X. L. and Wang, J. J. 2011. Triennial Growth Symposium: Important roles for L-glutamine in swine nutrition and production. Journal of Animal Science 89:2017-2030. https:// doi.org/10.2527/jas.2010-3614

Yin, J.; Li, X.; Li, D.; Yue, T.; Fang, Q.; Ni, J.; Zhou, X. and Wu, G. 2009. Dietary supplementation with zinc oxide stimulates ghrelin secretion from the stomach of young pigs. The Journal of Nutritional Biochemistry 20:783-790. https://doi.org/10.1016/j. jnutbio.2008.07.007

Zhang, Z. F.; Rolando, A. V. and Kim, I. H. 2016. Effects of benzoic acid, essential oils and Enterococcus faecium SF68 on growth performance, nutrient digestibility, blood profiles, faecal microbiota and faecal noxious gas emission in weanling pigs. Journal of Applied Animal Research 44:173-179. https://doi.org/ 10.1080/09712119.2015.1031765

Zhao, D.; Bakirtzi, K.; Zhan, Y.; Zeng, H.; Koon, H. W. and Pothoulakis, C. 2011. Insulin-like growth factor-1 receptor transactivation modulates the inflammatory and proliferative response of neurotensin in human colonic epithelial cells. The Journal of Biological Chemistry 286:6092-6099. https://doi.org/ 10.1074/jbc.M110.192534w 